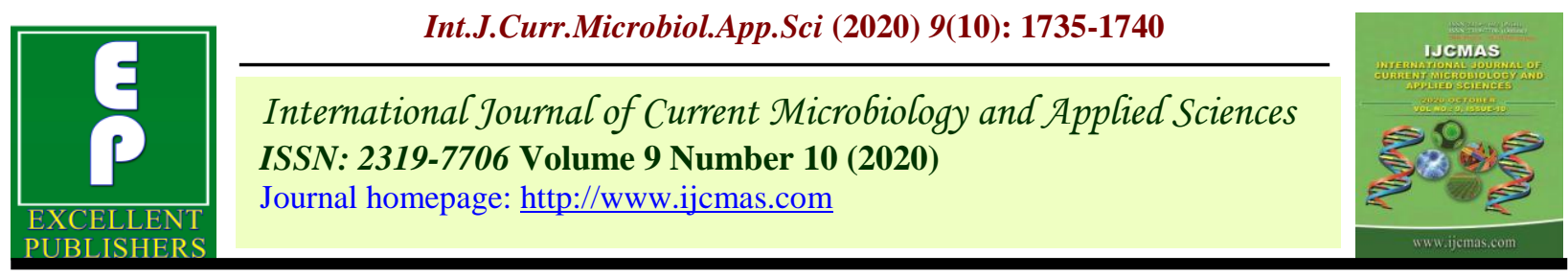

Original Research Article

https://doi.org/10.20546/ijcmas.2020.910.210

\title{
Nutrient Management in Rabi Blackgram
}

\author{
E. Aruna*, G. Karuna Sagar and A. Pratapkumar Reddy \\ Agricultural Research Station, Utukur, Kadapa, India \\ *Corresponding author
}

\begin{abstract}
A B S T R A C T
Keywords

Blackgram,

Nutrient

management, Rabi

Article Info

Accepted:

15 September 2020

Available Online:

10 October 2020

An experiment was conducted during the rabi seasons of 2018 and 2019 at Agricultural Research Station, Utukur, kadapa to study the effect of potassium and sulphur in addition to recommended nutrients of nitrogen and phosphorus on growth and yield of blackgram. The experiment was laid out in randomized block design with 11 treatments of different levels of nitrogen, phosphorus, potassium and sulphur. The results revealed that application of potassium and sulphur to rabi blackgram along with recommended dose of nitrogen and phosphorus influenced the plant height, number of branches per plant and pods per plant. Length of the pod, seeds per pod and 100 seed weight were not influenced by these nutrients. Application of 20-75-20-20 kg NPKS ha-1 recorded higher seed yield of 2256 and $1904 \mathrm{~kg} \mathrm{ha}^{-1}$ in 2017 and 2018.
\end{abstract}

\section{Introduction}

Blackgram is a short duration pulse crop grown in all seasons with little amount of water. It can fit very well in intensive cropping systems. It is a perfect combination of all nutrients like proteins (25-26\%), carbohydrates $(60 \%)$, fats $(1.5 \%)$, minerals, amino acids and vitamins. It is rich in vitamin A, B1, B3 and has small amount of thiamine, riboflavin, niacin and vitamin $\mathrm{C}$. It also has very high calorie content with $100 \mathrm{gm}$ of black gram containing 347 calories. Despite of all these features, the productivity of crop is below the average owing to several inherent soil related constraints such as low organic matter and poor soil fertility. Increase of pulse production is urgently needed to meet up the demand of the people to reduce import, to save foreign currency and to increase pulse consumption for maintaining good health. Hence, there is a need to enhance its productivity by different means. It can meet its nitrogen requirements by symbiotic fixation of atmospheric nitrogen. The nutrients which need attention are phosphorus, potassium and sulphur (Nandal et al., 1987). Potassium plays a critical role in enzyme activation, water use efficiency, photosynthesis, transport of sugars, protein and starch synthesis in plants (Muchena and Kiome, 1995) and is especially important in its interaction with nitrogen throughout the growing period. Blackgram is also very much responsive to sulphur application (Aulakh, et $a l .$, 1997). In recent years, sulphur deficiency 
has been aggravated in soils due to increase in cropping intensity and addition of sulphur free fertilizers. Sulphur is now recognized as the fourth major nutrients after $\mathrm{N}, \mathrm{P}$ and $\mathrm{K}$. The increasing concerns of sulphur deficiency suggest that $\mathrm{S}$ deserves greater attention than that it has received so far.

According to Tandon (1995), black gram yielding $8.90 \mathrm{qha}^{-1}$ removes $70 \mathrm{~kg} \mathrm{~N}, 5.6 \mathrm{~kg}$ $\mathrm{P}, 50.1 \mathrm{~kg} \mathrm{~K}$ and $5.1 \mathrm{~kg} \mathrm{~S}^{-1}$ from the soil. Hence, phosphorus, potassium and sulphur can improve the quality and quantity of the crop. Though the blackgram requires potassium and sulphur, the recommended dose of fertilizers for pulses include $20-50 \mathrm{~kg}$ $\mathrm{N}$ and $\mathrm{P} \mathrm{ha}{ }^{-1}$ only in this region. Therefore application of potassium and sulphur fertilizers becomes important both from quality as well as production point of view. Hence the present experiment was taken up to study the effect of potassium and sulphur on growth and yield of black gram.

\section{Materials and Methods}

A field experiment was conducted during rabi seasons of 2017 and 2018 at Agricultural Research Station, Utukur, Kadapa, Andhra Pradesh. The soil of the experimental site was analyzed and it was clayey loam with low nitrogen (139 $\left.\mathrm{kg} \mathrm{ha}^{-1}\right)$, medium phosphorus $\left(87 \mathrm{~kg} \mathrm{ha}^{-1}\right)$ and potassium $\left(460 \mathrm{~kg} \mathrm{ha}^{-1}\right)$ with $\mathrm{P}^{\mathrm{H}}$ of 7.9 and $\mathrm{EC}$ of $0.06 \mathrm{dS} / \mathrm{m}$. The experiment was laid out in randomized block design with 11 treatments viz., $20 \mathrm{~kg} \mathrm{~N}-50 \mathrm{~kg}$ $\mathrm{P}, 20 \mathrm{~kg} \mathrm{~N}-75 \mathrm{~kg} \mathrm{P}, 20 \mathrm{~kg} \mathrm{~N}-50 \mathrm{~kg} \mathrm{P}-10 \mathrm{~kg}$ $\mathrm{K}, 20 \mathrm{~kg} \mathrm{~N}-75 \mathrm{~kg} \mathrm{P}-10 \mathrm{~kg} \mathrm{~K}, 20 \mathrm{~kg} \mathrm{~N}-50 \mathrm{~kg}$ P- $20 \mathrm{~kg} \mathrm{~K}, 20 \mathrm{~kg} \mathrm{~N}-75 \mathrm{~kg}$ P- $20 \mathrm{~kg} \mathrm{~K}, 20 \mathrm{~kg}$ N- $50 \mathrm{~kg} \mathrm{P}-10 \mathrm{~kg} \mathrm{~K}-10 \mathrm{~kg} \mathrm{~S}, 20 \mathrm{~kg} \mathrm{~N}-75 \mathrm{~kg}$ P-10 kg K-10 kg S, $20 \mathrm{~kg} \mathrm{~N}-50 \mathrm{~kg} \mathrm{P} \mathrm{-} 20 \mathrm{~kg}$ $\mathrm{K}-20 \mathrm{~kg} \mathrm{~S}, 20 \mathrm{~kg} \mathrm{~N}-75 \mathrm{~kg} \mathrm{P}-20 \mathrm{~kg} \mathrm{~K}-20 \mathrm{~kg} \mathrm{~S}$ and 19:19:19 sprays at 30 and 45 DAS in RBD design. The crop was sown with yellow mosaic resistant TBG-104 variety on $10^{\text {th }}$ and $13^{\text {th }}$ October during 2017 and 2018 respectively with spacing $30 \mathrm{~cm} \times 10 \mathrm{~cm}$. All the fertilizers were applied basal at the time of sowing. The data on growth and yield parameters was taken at the time of harvest by taking five plants randomly from the plot. The data thus obtained was analysed statistically by using OP stat software.

\section{Results and Discussion}

\section{Effect on growth}

Taller plants were recorded with application of 20-50 -10 -10 kg NPKS ha- ${ }^{-1}\left(\mathrm{~T}_{7}\right)$ during both the years 2017 and 2018 with mean plant height of $32.38 \mathrm{~cm}$ (Table 1). It was on par with application of 20- $75-10-10 \mathrm{~kg}$ NPKS $\mathrm{ha}^{-1}\left(\mathrm{~T}_{8}\right)$. Taller plants with potash and sulphur application might be due to their role in stimulation of cell division, cell expansion, synthesis of chlorophyll and photosynthetic process. Lower plant height was recorded with application of 19:19:19 spray twice at 30 and 45 DAS $\left(T_{11}\right)$ in both the years. Increased plant height of blackgram with application of sulphur was also reported by Gokhilaet al., (2017) in Coimbatore soils and Thesiyaet al., (2013) in Junaghadh. Higher number of branches per plant was recorded with application of 20-50-10-10 kg NPKS ha-1 $\left(\mathrm{T}_{7}\right)$ and it was on par with other potassium and sulphur applied treatments in both the years indicating positive influence potassium and sulphur on growth of blackgram.

\section{Effect on yield attributes and yield}

Significantly higher number of pods per plant was observed with application of 20-50 -10 $10 \mathrm{~kg} \mathrm{NPKS} \mathrm{ha}{ }^{-1}\left(\mathrm{~T}_{7}\right)$ in both the years with mean of 56.16. It was on par with 20-75 -20 $20 \mathrm{~kg} \mathrm{NPKS} \mathrm{ha-1}\left(\mathrm{T}_{10}\right)$ in 2018. Lower number of pods per plant was recorded with application of 19:19:19 spray twice at 30 and 45 DAS $\left(T_{11}\right)$ in both the years. 
Table.1 Growth and yield of blackgram (TBG -104) as influenced by nutrient management

\begin{tabular}{|c|c|c|c|c|c|c|c|c|c|c|c|c|c|}
\hline & \multirow{2}{*}{$\begin{array}{l}\text { Fertiliser dose } \\
\quad\left(\mathrm{Kg} \mathrm{ha}^{-1}\right)\end{array}$} & \multicolumn{3}{|c|}{ Plant height $(\mathrm{cm})$} & \multicolumn{3}{|c|}{ No. of branches /plant } & \multicolumn{3}{|c|}{ No. of pods /plant } & \multicolumn{3}{|c|}{ Pod Length (cm) } \\
\hline & & 2017 & 2018 & mean & 2017 & 2018 & mean & 2017 & 2018 & mean & 2017 & 2018 & mean \\
\hline T1 & $20 \mathrm{~N}-50 \mathrm{P}(\mathrm{RDF})$ & 32.43 & 23.35 & 27.89 & 3.06 & 3.06 & 3.06 & 40.46 & 38.86 & 39.66 & 4.15 & 4.88 & 4.51 \\
\hline $\mathbf{T} 2$ & $20 N-75 P$ & 33.66 & 23.00 & 28.18 & 3.40 & 3.28 & 3.34 & 37.40 & 42.40 & 39.90 & 4.28 & 5.07 & 4.67 \\
\hline T3 & $20 N-50 P-10 K$ & 34.93 & 23.73 & 29.33 & 3.60 & 3.56 & 3.58 & 44.93 & 43.60 & 44.26 & 4.56 & 5.17 & 4.86 \\
\hline T4 & $20 N-75 P-10 K$ & 32.66 & 22.40 & 27.53 & 3.53 & 3.53 & 3.53 & 45.53 & 42.93 & 44.23 & 4.36 & 4.90 & 4.63 \\
\hline T5 & $20 N-50 P-20 K$ & 33.46 & 21.13 & 27.29 & 3.53 & 3.30 & 3.41 & 39.13 & 40.00 & 39.56 & 4.53 & 4.92 & 4.72 \\
\hline T6 & $20 N-75 P-20 K$ & 35.73 & 23.83 & 29.78 & 3.80 & 3.33 & 3.56 & 40.20 & 44.26 & 42.23 & 4.64 & 4.89 & 4.76 \\
\hline T7 & $20 N-50 P-10 K-10 S$ & 37.76 & 27.00 & 32.38 & 4.13 & 3.86 & 3.99 & 57.20 & 55.13 & 56.16 & 4.50 & 5.07 & 4.78 \\
\hline T8 & $20 N-75 P-10 K-10 S$ & 35.43 & 24.06 & 29.74 & 3.58 & 3.36 & 3.41 & 40.46 & 41.73 & 41.09 & 4.50 & 5.00 & 4.75 \\
\hline T9 & $20 N-50 P-20$ K- $20 S$ & 34.40 & 23.33 & 28.86 & 3.64 & 3.36 & 3.41 & 44.00 & 45.00 & 44.50 & 4.63 & 5.18 & 4.90 \\
\hline T10 & $20 N-75$ P - 20 K- $20 S$ & 34.50 & 26.20 & 30.35 & 3.62 & 3.30 & 3.35 & 48.40 & 51.50 & 49.95 & 4.50 & 4.90 & 4.78 \\
\hline T11 & $\begin{array}{l}\text { 19:19:19 spray twice } \\
\text { at } 30 \text { and } 45 \text { DAS }\end{array}$ & 26.30 & 20.20 & 23.25 & 2.93 & 2.53 & 2.73 & 24.90 & 33.26 & 29.08 & 3.89 & 4.87 & 4.38 \\
\hline & S.E m \pm & 1.08 & 1.04 & & 0.19 & 0.19 & & 1.35 & 1.73 & & 0.10 & 0.13 & \\
\hline & CD at $5 \%$ & 3.20 & 3.09 & & 0.56 & 0.56 & & 4.02 & 5.14 & & 0.32 & NS & \\
\hline & CV & 5.54 & 7.67 & & 9.31 & 10.1 & & 5.76 & 6.89 & & 4.21 & 4.78 & \\
\hline
\end{tabular}


Table.2 Growth and yield of blackgram (TBG -104) as influenced by nutrient management

\begin{tabular}{|c|c|c|c|c|c|c|c|c|c|c|}
\hline & \multirow{2}{*}{$\begin{array}{l}\text { Fertiliser dose } \\
\left(\mathrm{Kg} \mathrm{ha}^{-1}\right)\end{array}$} & \multicolumn{3}{|c|}{ No. of seeds/pod } & \multicolumn{3}{|c|}{100 seed wt (g) } & \multicolumn{3}{|c|}{ Seed yield $\left(\mathrm{kg} \mathrm{ha}^{-1}\right)$} \\
\hline & & 2017 & 2018 & mean & 2017 & 2018 & mean & 2017 & 2018 & mean \\
\hline T1 & $20 \mathrm{~N}-50 \mathrm{P}$ (RDF) & 6.93 & 6.26 & 6.59 & 5.64 & 5.27 & 5.45 & 1943 & 1568 & 1755 \\
\hline $\mathbf{T 2}$ & $20 N-75 P$ & 6.80 & 6.60 & 6.70 & 5.63 & 5.25 & 5.44 & 2001 & 1667 & 1834 \\
\hline T3 & $20 N-50 P-10 K$ & 6.96 & 6.80 & 6.88 & 5.69 & 5.31 & 5.50 & 2035 & 2024 & 2029 \\
\hline T4 & $20 N-75 P-10 K$ & 6.83 & 6.36 & 6.59 & 5.46 & 5.50 & 5.48 & 2229 & 1742 & 1986 \\
\hline T5 & $20 N-50 P-20 K$ & 6.73 & 6.46 & 6.59 & 5.53 & 5.44 & 5.48 & 2010 & 1859 & 1934 \\
\hline T6 & $20 N-75 P-20 K$ & 6.50 & 6.93 & 6.71 & 5.75 & 5.27 & 5.51 & 2053 & 2039 & 2046 \\
\hline $\mathbf{T 7}$ & $20 N-50 P-10 K-10 S$ & 6.86 & 6.76 & 6.81 & 5.77 & 5.26 & 5.51 & 2035 & 1861 & 1948 \\
\hline T8 & $20 N-75 P-10 K-10 S$ & 6.83 & 7.06 & 6.94 & 5.77 & 5.29 & 5.53 & 2112 & 1799 & 1955 \\
\hline T9 & $20 N-50 P-20$ K- $20 S$ & 6.83 & 6.46 & 6.64 & 5.69 & 5.31 & 5.50 & 2110 & 1854 & 1982 \\
\hline T10 & $20 N-75$ P -20 K- $20 S$ & 6.93 & 6.66 & 6.79 & 5.81 & 5.32 & 5.56 & 2256 & 1904 & 2080 \\
\hline \multirow[t]{4}{*}{ T11 } & $\begin{array}{l}\text { 19:19:19 spray twice } \\
\text { at } 30 \text { and } 45 \text { DAS }\end{array}$ & 6.36 & 6.36 & 6.36 & 5.47 & 4.88 & 5.17 & 1568 & 1454 & 1511 \\
\hline & & 0.17 & 0.30 & & 0.14 & 0.08 & & 83 & 105 & \\
\hline & & NS & NS & & NS & NS & & 246 & 311 & \\
\hline & & 4.38 & 7.93 & & 4.35 & 2.88 & & 6.93 & 6.97 & \\
\hline
\end{tabular}


Application of potassium and sulphur might have increased the translocation of these nutrients from source to sink (seed) which would have increased the number of pods per plant. This result was in conformity with the findings of Kokani et al., (2014) who had reported increased number of pods in blackgram with application of S @ $20 \mathrm{~kg} \mathrm{ha}^{-1}$.

Lengthier pods of blackgram $(4.66 \mathrm{~cm})$ was observed with the application of 20-50 -10 $10 \mathrm{~kg} \mathrm{NPKS} \mathrm{ha-1}\left(\mathrm{T}_{7}\right)$ in 2017 but it was on par with other treatments except $20-50 \mathrm{~kg} \mathrm{~N}$ and $\mathrm{P}\left(\mathrm{T}_{1}\right), 20-75 \mathrm{~kg} \mathrm{~N}$ and $\mathrm{P}\left(\mathrm{T}_{2}\right)$ and 19:19:19 spray twice at 30 and $45 \mathrm{DAS}\left(\mathrm{T}_{11}\right)$. During 2018, potassium and sulphur application did not significantly influence the length of pods in blackgram. Number of seeds per pod and 100 seed weight in blackgram were not significantly influenced by treatments in both the years. Whereas, Vaiyapuri et al., (2010) revealed that application of $\mathrm{S} @ 30 \mathrm{~kg} \mathrm{ha}{ }^{-1}$ increases all yield attributing characters viz., no. of branches plant-1, no. of pods plant ${ }^{-1}$, no. of seeds $\operatorname{pod}^{-1}$ and 100 seed weight of soybean due to better plant metabolism.

Application of 20-75-20-20 kg NPKS ha $\left(\mathrm{T}_{10}\right)$ recorded higher seed yield of 2256 and $1904 \mathrm{~kg} \mathrm{ha}^{-1}$ respectively in 2017 and 2018 (Table 2). It was on par with other treatments except 20 - $50 \mathrm{~kg} \mathrm{~N}$ and $\mathrm{P}\left(\mathrm{T}_{1}\right), 20-75 \mathrm{~kg} \mathrm{~N}$ and $\mathrm{P}\left(\mathrm{T}_{2}\right)$ and 19:19:19 spray twice at 30 and 45 DAS $\left(\mathrm{T}_{11}\right)$ indicating the significant influence of potassium and sulphur on growth and yield of rabi blackgram. Beneficial role of potash and sulphur on photosynthetic process and enzyme activation might have improved the yield. Basumatary et al., (2018) also reported increased grain and stover yield of blackgram significantly up to $20 \mathrm{~kg} \mathrm{~S}^{-1}$ which was $95.69 \%$ higher over control. But reported higher Agronomic efficiency, apparent sulphur recovery and recovery efficiency at $10 \mathrm{~kg} \mathrm{~S} \mathrm{ha}^{-1}$ and found decreased with increase in level of sulphur.
It can be concluded that application of potassium and sulphur along with recommended dose of nitrogen and phosphorus influenced growth and yield of blackgram in kadapa region of Andhrapradesh. Hence $10 \mathrm{~kg}$ each of potassium and sulphur can be recommended to rabi blackgram along with recommended nitrogen $(20 \mathrm{~kg})$ and phosphorus $(50 \mathrm{~kg})$ in kadapa region of Andhra Pradesh.

\section{References}

Basumatary, A., Shangne, J. J., Das, K. N., and Bhattacharyya, D. 2018. Impact of sulfur fertilization on distribution of sulfur fractions and use efficiency in blackgram in subtropical acidic soil of Assam, India. Journal of Plant Nutrition.41: 1436-1443.

Gokhila, B., Bhaskar, K., and Saravanapandian.2017. Nutritional significance of sulphur on growth, yield and quality of blackgram in major contrasting soil series of Tamilnadu, India. International Journal of current microbiology and applied sciences 6(11): 3139-3149.

Kokani, J.M., Shah, K.A.,Tandel., and Nayaka,P.2014. Growth, yield attributes and yield of summer blackgram (Vigna mungo L.) as influenced by FYM, phosphorus and sulphur. The Bioscan. 6: 429-433.

Muchena, F., andKiome,R.1995. The role of soil science in agriculture development in east Africa. Geoderma 67:141-157.

Nandal, D.P., Malik, D.S., and Singh, K.P. 1987. Effect of phosphorus levels on drymatter accumulation of kharif pulses. Legume Research 19:31-33.

Tandon.1995.Sulphurfertilisers for Indian Agriculture- A guide book II edn. Fertilizer development and consultation organization, New Delhi.1-20.

Thesiya, N.M., Chovati, P.K., and Kikani,V.L. 2013. Effect of potassium 
and sulphur on growth and yield of blackgram under rainfed conditions. Legume Research 36(3): 255-258.

Vaiyapuri, K., Mohamed Amanullah, M., and

Rajendran, K. 2010. Influence of sulphurand boron on yield attributes and yield of soybean. Madras Agric. J.97 (13): 65-67.

\section{How to cite this article:}

Aruna, E., G. Karuna Sagar and Pratapkumar Reddy, A. 2020. Nutrient Management in Rabi Blackgram. Int.J.Curr.Microbiol.App.Sci. 9(10): 1735-1740.

doi: https://doi.org/10.20546/ijcmas.2020.910.210 